\title{
Challenges of Early Years leadership preparation: a comparison between early and experienced Early Years practitioners in England
}

Management in Education

26(I) 28-37

(C) 2012 British Educational Leadership, Management \& Administration Society (BELMAS)

Reprints and permission:

sagepub.co.uk/journalsPermissions.nav DOI: 10.1 | 177/08920206 | |427068

mie.sagepub.com

(S)AGE

\author{
Malini Mistry \\ University of Bedfordshire \\ Krishan Sood \\ Nottingham Trent University
}

\begin{abstract}
Leadership has been under-researched in the Early Years (EY) sector of primary schools in England, especially in leading change for professional development. The aim of this paper is to theorise what the leadership culture for EY practitioners looks like, and how Initial Teacher Training providers and schools are preparing practitioners for leadership. Using case studies of EY practitioners in different stages of their career in primary schools, we offer an insight into their preparedness for leadership in EY, the implication being that leadership training requires an understanding and embedding of the EY culture and context. Interviews with both sample groups allowed for deeper insight into the lived world. Interviews were also conducted with the head teachers to gain an overview of the leadership preparation they provided. The main findings suggest that newer EY practitioners are better prepared for leadership from their university training in comparison to more experienced EY practitioners.
\end{abstract}

\section{Keywords}

Early Years and leadership

\section{Introduction}

The EY services in England provide a crucial role in ensuring the quality of care for children and their families. An even greater challenge has been posed for leadership to provide quality care under reduced financial and other resources (Randall, 2000; Lloyd, 2008). The Early Years Foundation Stage (EYFS) consists of six areas of learning and became statutory in 2004 for all registered settings with children from birth to five years; however, this is now in the process of being reviewed under the new British Coalition government. The EYFS also offers an external benchmark for the provision of education and care to all children under school age.

Early educational settings in England are diverse, including nursery classes, primary schools, and private and voluntary settings (Dunlop, 2002; Solly, 2003; Muijs et al., 2004). The first challenge for leadership is to bring cohesion among different groups of adults in EY sharing the same vision. Another challenge within EY (age range 3-5) in primary schools is how best to develop a coherent policy on continuous professional development (CPD) when there are so many different agencies and multiple functions to manage.

EY practitioners already lead a variety of other adults in their settings due to the contextual nature of EY. However, when this is compared to leadership within the whole school, EY leaders seem reluctant to take on wholeschool leadership roles. Part of this reason may be that EY leadership in some primary schools is not given enough importance. Greater priority appears to be targeted to those members of staff engaged with examination classes like Year 2 (children aged 6-7) and Year 6 (children aged 10-11) or those members of staff who are responsible for core subject leadership such as English and Mathematics. Rodd (2006) has highlighted the reluctance among leaders in the EY to accept the label of leader. EY leaders often express an aversion towards the management aspects of the job, which are seen to take them away from their preferred status as educators and child developers. In addition to the feared loss of time and input to supporting child development, there is also the feeling of a sense of incompetence, which is magnified by the lack of training offered in such tasks as budgeting and the management of adults. There is a difference between leadership and management, where leadership is seen to focus on people and management is concerned with achieving results (Armstrong \& Stephens, 2006: 5). This is of course an artificial divide but the

\section{Corresponding author:}

Malini Mistry, University of Bedfordshire, Polhill Avenue, Bedford, MK4I 9EA, United Kingdom

E-mail: malini.mistry@beds.ac.uk 
distinction is important because management is mainly about deployment and control of resources but, where people are concerned, there has to be effective leadership to deliver results. According to Bennis \& Nanus (1995) managers do things right while leaders do the right things. In terms of EY, leadership and management are tightly intertwined due to the context of the working environment, therefore at times it is difficult to distinguish each one separately.

\section{Literature}

We reflect on some of the issues to do with vision setting (Gronn, 1999), transformational leadership (Leithwood \& Jantzi, 2005), strategic leadership (Davies \& Davies, 2005) and cultural leadership (Cheng, 1995; Dimmock \& Walker, 2000, 2005) and see if the gender of leaders is material or not in the EY context (Boone, 2004). Moss (2006) identified the push by the British government into raising the quality and status of EY practice and provision, but to date there are only a handful of reports from which learning about EY leadership can be discerned. Leadership is complex and requires competences and a variety of traits to manage complexity. Among the emerging leadership traits are flexibility, energy, enthusiasm, compassion, humbleness and a vision which is inspirational (O'Sullivan, 2010: online). Muijs et al. (2004) suggest that leadership therefore matters in programmes being successful or failures. They go on to suggest success comes about with leadership that is committed, competent and skilful at training and supervising staff. This has implications for trainers in higher education or in schools to create conditions for EY leaders to develop their leadership and management abilities by undertaking some tasks associated with their context (Rodd, 2006). These conditions are to do with mentoring and coaching opportunities, commitment to continuous professional development and where professional dialogue about pedagogy and learning is encouraged. Cable \& Miller (2011: 147) note the need for further research to 're-conceptualise and reconstruct' what it means to be a professional in the EY.

Siraj-Blatchford \& Manni (2007) note that transition from managing children to managing adults is difficult to make by EY professionals. There is no doubt that the development of leadership preparation and qualifications is increasing, such as Early Years Professional Status (EYPS) (CWDC, 2011a: online), the National Professional Qualification in Integrated Centre Leadership (NPQICL) (DfES, 2007b), the National Standards for Children's Centre Leaders and the Children's Workforce Development Council (CWDC) (2011b: online) for the occupational standards for EY leadership and management.

\section{Leadership in the Early Years}

The EY workforce itself comprises a wide range of personnel, each with different experience, training and qualifications. Notable and perceptibly more rewarding aspects of developing people are to do with the development of human relations, but this can be a double-edged sword in that managing people's expectations, values and beliefs and their opportunities for development of the self are up against role conflict and the culture of the organisation. This requires both sensitive handling and diplomacy. What appears to be unique within the EY sector is the higher proportion of young and inexperienced staff which has implications for leadership styles (Solly, 2003).

The multiple roles that EY practitioners are engaged in casts some tension with what roles they play, as sometimes they are leaders and at other times they are managers. This is because the diversity of this workforce makes a particularly complex arena for leadership (Rodd, 2006). Historically this workforce rarely had leadership training and it is likely that some individuals were therefore significantly underprepared for this role. Drawing from the work of early childhood practitioners suggests that too often positions of leadership in early childhood settings tended to be held by accidental leaders with minimal training to carry out their responsibilities (Ebbeck \& Waniganayake, 2003; Rodd, 2006).

\section{Early Years leadership: views of cultural leadership, transformational leadership and leadership from a feminist perspective}

Culture is a key force that influences the leadership of individuals (Gronn, 1999). Gronn's (1999) conceptual framework is one helpful model for reflecting on how EY practitioners can be prepared for the five leadership characteristics of: vision building, ethical considerations, teaching and learning, power utilisation, and dealing with risks and challenges. Experienced leaders perhaps demonstrate these constantly and the suggestion here is that EY practitioners can learn from the best leadership approaches. Leithwood \& Jantzi (2005) have refined the notion of transformational leadership, noting that experienced leaders have a role in developing a person by offering intellectual stimulus and providing individual support to teachers. Furthermore, they go on to suggest that such leaders need to create a collaborative learning community by redesigning the organisation, which has implications for involving, listening and reacting to different voices of the professional staff.

Davies \& Davies (2005) offer a perspective of change management by suggesting that leadership requires strategic alignment to intention (where we are going and how we get there) and this involves 'people wisdom' (p. 23), a 'contextual wisdom' (p. 23) and a 'procedural wisdom' (p. 26). So the new leadership may well require developing one's own mental schema of the desired future based on harnessing the abilities of others. Greenfield \& Ribbins (1993) critique the epistemological and ontological assumptions of leadership, pointing out that we need to be concerned more with bridging individual identity, value and emotion with the social structures and systems of an organisation. Gronn (1999) believes that leadership is influenced by culture and society, but we wonder if leadership preparation relates to any degree to such dimensions, given 
the diversity of the workforce (see Cheng, 1995; Dimmock \& Walker, 2000, 2005).

We now turn to a critical discussion of feminist research on leadership to look at its impact on the EY workforce which remains largely female (Roberts-Holmes \& Brownhill, 2011: 119, in Miller and Cable, 2011: 57). Some research studies suggest that feminine attributes in female leaders are more suited for leadership in the twenty-first century (Boone, 2004). Conceivably, these attributes are to do with exhibiting democratic, inclusive and collaborative behaviour (Zhong, 2009), and the notion that women are better at listening, caring and nurturing (Shakeshaft, 1989) than men remains contestable. EY leaders experience lower salaries in comparison to other leadership and management roles within a school which could deter men, while the other controversial reason is the gay/paedophile stereotype that is prevalent in the media which again hinders male leadership in EY. Perhaps it is time to question the appropriateness of the traditional masculine model of leadership to look at the effectiveness of feminine leadership traits. As Boone (2004) suggests, the leadership for tomorrow's schools may well be more situational and androgynous in nature. Boone (2004) also claims that leadership is a matter of personality and philosophy not gender. The literature suggests that educational leadership is firmly rooted in professional identity and 'to understand one, we must understand the other' (Hall, 1997: 370). We also need to understand gender bias in leadership by critiquing multilevel, complexity theory (Hogue \& Lord, 2007), which shows why multiple solutions applied at individual, group, and organisational levels may all be required to study gender bias in leadership.

\section{Effective educational leadership in Early Years}

The more recent statements around educational leadership sit well with perceptions held within EY that effective EY leaders need qualities and skills which are related to team work, motivation, support, role definition and goal setting (Rodd, 2006). Moyles (2006) considers the management skills to be more about effective human resource management and curriculum management. Siraj-Blatchford and Manni (2007) conclude that the role of leadership in EY is essentially that of leadership for learning and this requires understanding the context the leader is working in so that the leader can marshal effective support for effective pupil outcomes.

One of the challenges for EY leadership is how to encourage more male leaders to counterbalance the largely feminised workforce (Miller \& Cable, 2011: 24). A reason for this could be that EY leadership is an area that male practitioners feel uncomfortable in due to the nature of close working with very young children, and therefore there is a likelihood that greater judgement may be placed on them by people in comparison to their female colleagues (Miller \& Cable, 2011). But this is purely speculative and the need to theorise this area with evidence is urgently required. However, this opens up an interesting opportunity for radical debate within the whole spectrum of the education sector of professional identity in EY settings. The notion of 'collective identity' (Adams, 2008: 208) raises many issues which shows some of the difficulties in this area. McMillan and Walsh (2011, in Miller \& Cable, 2011: 57), reflecting on some of the issues, challenges and opportunities of EY professionalism, suggest that we need shared training and equality of resources to achieve professional identity.

We extend the debate about sexual identity here as there are many myths and stereotypes based on literature or assumptions that have been the subject of little critique. MacNaughton (2000) suggests that if Early Years educators are to address issues of gender and sexuality then they need their 'knowledge base to be expanded' (p. 237). Murray (1996) discusses men in childcare settings and posits that male EY educators are highly questionable and subject to considerable suspicion whereas Sumsion (2010) alluded in his study of gender positioning that 'negotiating otherness' was always a contentious and painful process. What is needed is a way of explaining such complex issues sensitively and in 'multiple ways through dialogue' (MacNaughton, 2000: 239). In addition, Johnson and Kossykh (2008) conclude that there is 'very little evidence on the interaction between experiences in early years and later life outcomes for gay and lesbian people ... This is largely because the datasets that contain information both on early years and on life outcomes do not collect information on sexual orientation' (p. v). The implications for Early Years trainees in the Initial Teacher Training institutions is that much more emphasis is needed in this area to develop trainees' own 'ethics of critical collectiveness' so that they feel adequately equipped to challenge and erode the myths and stereotype labels of men working in the EY education sector and making a career in this field. The Stonewall 'Sexual Orientation Research Review' (2007: 42) identifies this as a major gap in research:

\footnotetext{
... there has to date been no national survey of the current climate of homophobia in schools. Policy makers and education professionals would benefit from up-to-date evidence of the scale of the problem, including primary research among current lesbian and gay students about the issues they face.
}

The boundaries and resulting tensions between EY leadership preparation and experienced leaders suggest that the essence of dialogue to share meaning about authentic leadership and to identify gaps in the learning skills of EY leaders is important. Also, leaders in schools need to better align 'organisational values to the personal values of their teams' (Wallace \& Gravells, 2010: 102). Based on these challenges, we posed the following research questions in our study:

\section{Research questions:}

1. How well have EY practitioners been prepared for a leadership role from their university training? 
Table I. Sample size selection

\begin{tabular}{lll}
\hline Primary school A (sample size $=3)$ & Primary school B (sample size $=3)$ & Primary school C (sample size $=3)$ \\
\hline Teacher leader with 0-3 years' experience & Teacher leader with 0-3 years' experience & Teacher Leader with 0-3 years' experience \\
Teacher leader with 6+ years' experience & $\begin{array}{l}\text { Teacher leader with 6+ years' experience } \\
\text { Head teacher B }\end{array}$ & $\begin{array}{l}\text { Teacher leader with 6+ years' experience } \\
\text { Head teacher A }\end{array}$ \\
\hline
\end{tabular}

2. How is the transition from 'managing' children to 'managing' adults made by EY professionals?

3. How is leading in the EY phase different from wholeschool leadership through the lens of two sample groups?

4. What are the challenges for head teachers to address some of the differences?

\section{Research methods}

Three primary schools in the Midlands area in England were chosen because they had a large EY pupil population resulting therefore in more than one EY class in a setting with both new and more experienced EY practitioners. This proved to be a challenge in itself as there are very few schools with more than one EY class and staff at the two ends of experience. Opportunistic sampling therefore became a necessity. These schools are primary school A, primary school B and primary school $\mathrm{C}$. The way we have selected the sample size is shown in Table 1.

Each group of participants was interviewed through a structured interview schedule in order to gain an understanding of their preparedness for the leadership role, the selected participants being an example of the phenomenon of our study (Paton, 2002). The head teacher interviews provided the wider picture of leadership development within each school. For the first group of EY leaders (those in the first three years of teaching), questions were linked to their university training, as well as the induction support process they received upon employment. The second group of practitioners (those who had more than six years' teaching experience in EY), in addition to questions based on their university training and induction, were also asked about the professional development they had received to support them as leaders. Those in the second group generally had more than one leadership area of responsibility, including EY. For some of the more experienced leaders, the responsibility of EY came after a few years of teaching.

To ensure participant triangulation, interviews were also carried out with head teachers to gain an understanding of their vision for leadership in their setting and what support they provided in order to develop the best possible leaders. To meet ethical requirements, interviewees were promised anonymity and confidentiality and given the research purpose before being asked to give their consent. We acknowledge the very small size of the sample group and this clearly blurs the conclusions emanating from the such a small-scale study. Time was at a premium and the data presented here is selective of an earlier pilot questionnaire we had conducted with $40 \mathrm{EY}$ trainees as a result of their perception of EY leadership in their final teaching practice. So we decided on a balance between the depth and richness of data (Fogelman \& Comber, 2007: 126) and the resources available which imposed practical constraints on the number of interviews that could take place. The structured interviews were conducted in the same way in the different schools, with predetermined questions and following the same procedures. This gave us the confidence that we were being reliable. As Yin suggests, the researcher needs to undertake research 'as if someone were always looking over your shoulder' (2003: 146). The concept of validity is based on the assumption that the research accurately describes the phenomenon that it is intended to describe. To that end, therefore, we followed Bush's (2010) advice that the research design, methodology and conclusions of the research all need to have regard to the validity of the process (p. 97). Any attempt to use anecdotes to illustrate detailed issues was also avoided as this would have compromised validity in this qualitative research (Yin, 2003).

Analysis of the data followed the four stages suggested by Marshall \& Rossman (1995): firstly, organising the data; secondly, generating categories, themes and patterns; thirdly, testing any emergent hypothesis; and finally, searching for alternative explanations. This meant that the data from each interview (nine sections in total) were organised into groups for ease of synthesis. From this, we looked for common patterns emerging that fitted the research questions posed and highlighted these with a highlighter pen. The emerging data were then analysed against the analytical framework from the literature.

\section{Findings and discussion}

The findings of this study are presented in Tables 2-7 to make the data clear, which we now discuss through the main themes relating to our four research questions. Some additional research questions formed the interview schedule to further dissect comments in order to gain a deeper understanding. The themes are prepreparedness, transition, leadership and the challenges for schools.

The results suggest that those practitioners who were specialised in EY at university more than six years ago had very little training on leadership and how this informs practice. Some commented that all the direction they had towards a leadership role was to read particular texts or observe selected individuals. The main thrust was that they were expected to learn on the job with unknown expectations as to what they were actually supposed to do. Those practitioners who were within their first three years of teaching were more prepared for the role of subject leadership. Part of this was due to the fact that they had sessions at university on EY leadership whereby they deconstructed 
Table 2. How well have EY practitioners been prepared for a leadership role from their university training and from their in-school training?

\begin{tabular}{lcc}
\hline Question & New EY leaders (0-3 years' experience) & $\begin{array}{l}\text { More experienced EY leaders (6+ years' } \\
\text { experience) }\end{array}$ \\
\hline $\begin{array}{l}\text { What training did you have at your } \\
\text { university in relation to taking on a } \\
\text { leadership responsibility }\end{array}$ & $\begin{array}{c}\text { 'University sessions on subject leadership. More } \\
\text { leadership responsibilities in final placement.' } \\
\text { (School A: Teacher A) } \\
\text { 'Leadership lectures at university and assign- } \\
\text { ments.' (School B: Teacher A) }\end{array}$ & $\begin{array}{c}\text { Teacher B) } \\
\text { 'None for EY, but I was told to read a given } \\
\text { book for history of responsibility'. } \\
\text { (School B: Teacher B) }\end{array}$ \\
$\begin{array}{c}\text { 'Leadership and management module linked to } \\
\text { Career Entry Development Profile (CEDP).' (School A: } \\
\text { (School C: Teacher A) }\end{array}$ & $\begin{array}{c}\text { 'Nothing for leadership.' (School C: } \\
\text { Teacher B) }\end{array}$ \\
\hline
\end{tabular}

Table 3. Identifying the range of leadership tasks undertaken

\begin{tabular}{lll}
\hline Question & $\begin{array}{l}\text { New EY leaders (0-3 years' } \\
\text { experience) }\end{array}$ & $\begin{array}{l}\text { More experienced EY leaders (6+ years' } \\
\text { experience) }\end{array}$ \\
\hline $\begin{array}{c}\text { As someone who has specialised in EY at } \\
\text { university, what do you have leadership } \\
\text { responsibility for? }\end{array}$ & $\begin{array}{c}\text { 'Have responsibility for EY.' } \\
\text { (School A: Teacher A) }\end{array}$ & $\begin{array}{c}\text { 'Currently: EY, ICT and Geography.' (School A: } \\
\text { Teacher B) }\end{array}$ \\
& $\begin{array}{l}\text { I have responsibility for EY and } \\
\text { lead transition in KSI.' (School } \\
\text { B: Teacher A) }\end{array}$ & $\begin{array}{c}\text { 'Currently: EY, transition into YI, ICT, KSI Reading, } \\
\text { parent link worker. Past: literacy, and KSI.' } \\
\text { (School B: Teacher B) }\end{array}$ \\
& $\begin{array}{c}\text { Currently, it's EY and art.' (School 'Currently: EY, SEN, and music. Past: assessment in } \\
\text { C: Teacher A) }\end{array}$ & KSI.' (School C: Teacher B) \\
\hline
\end{tabular}

the role of the leader and therefore gained an awareness of what the role involves, including aspects such as policy writing, action planning and data analysis, before reconstructing the role in relation to their personal style in accordance with the context of their setting.

Head teachers from all schools commented that the newer practitioners have a better understanding of leadership therefore they have to spend less time showing them what to do. Whalley (2011, cited in Miller \& Cable, 2011) notes that the key roles of leadership and management within the contemporary children's workforce in England have only recently received attention. Whalley (2011) goes on to suggest that research confirms the key role of leadership in creating effective organisations but we found limited literature linking the role higher education is specifically playing in the preparation for EY leadership. In our view, higher education institutions are already addressing concepts like vision, collegiality, trust, openness, planning, leading and managing (Moyles, 2006) within the concept of distributed leadership, but whether the trainees are reflecting on what distributed leadership means in practice remains to be investigated and evaluated.

The results in Table 3 indicate that EY practitioners have a variety of other responsibilities including EY. Although some of the more experienced practitioners were EY trained, they did not necessarily acquire responsibility for EY on appointment - the EY responsibility would depend on the needs in the school at the time. Many of the experienced EY practitioners also commented that they have many other areas of responsibility in addition to EY as, again, EY is not seen to be as important as other core subjects such as English and Maths. However, newer EY practitioners were appointed to EY positions and given responsibility for EY by the end of their second year of teaching. In that way schools have become more focused on the strengths of their staff and are matching them more appropriately to their relevant skills, something that may not always have happened in the past.

Comments from head teachers suggest that they offer a range of opportunities for the EY practitioners, like 'giving them other curriculum responsibilities other than EY' or 'ensuring that they are working as a team with other staff in the school on teaching and learning plans'. Sharing key tasks like curriculum development and teaching and learning policy development accords with the notion of developing a person (Leithwood \& Jantzi, 2005) and within the contextual wisdom (Davies \& Davies, 2005) allows for risk-taking and dealing with challenges (Gronn, 1999). One head commented that it was important for the EY practitioners to ' $\mathrm{mix}$ with the other staff in the school so that they are not isolated', allowing time for the inexperienced and the experienced to exchange views on pedagogy or for socialising. This is crucial in creating a collaborative learning community that requires the leaders to create spaces for engagement with discourse and reflection (O'Sullivan, 2010: online).

The results in Table 4 suggest that initially all EY staff were afraid to manage other staff in the school within the different areas of subject leadership. This again is related to the fact that contextually EY is not seen to be important and therefore responsibility for it is not seen to be important in comparison to other subjects. The evidence suggests that many are worried about making the transitional change from managing children to managing adults, which requires 
Table 4. How is the transition made from 'managing' children to 'managing' adults by EY professionals?

\begin{tabular}{|c|c|c|}
\hline Question & New EY leaders (0-3 years' experience) & More experienced EY leaders (6+ years' experience) \\
\hline \multirow[t]{3}{*}{$\begin{array}{l}\text { How did you find the transition } \\
\text { from managing children to } \\
\text { managing adults? }\end{array}$} & $\begin{array}{l}\text { 'Am worried as other adults in the school as } \\
\text { they are more experienced.' (School A: } \\
\text { Teacher A) }\end{array}$ & $\begin{array}{l}\text { 'It was hard making the transition from managing } \\
\text { children to adults.' (School A: Teacher B) }\end{array}$ \\
\hline & $\begin{array}{l}\text { 'Am used to working with a nursery nurse, } \\
\text { but other TAs have a lack of EY knowl- } \\
\text { edge.' (School B: Teacher A) }\end{array}$ & $\begin{array}{l}\text { 'Need to be clear with your expectations without } \\
\text { causing offence, being open to suggestions and being } \\
\text { a critical friend.' (School B: Teacher B) }\end{array}$ \\
\hline & $\begin{array}{l}\text { 'Working with others was one of QTS stan- } \\
\text { dards so it was OK.' (School C: Teacher A) }\end{array}$ & $\begin{array}{l}\text { 'Difficult initially as you were seen to be the NQT, } \\
\text { until another NQT was hired, then you were given a } \\
\text { little more respect.' (School C: Teacher B) }\end{array}$ \\
\hline
\end{tabular}

Table 5. How is leading in the EY phase different from whole-school leadership through the lens of two sample groups?

\begin{tabular}{|c|c|c|}
\hline Question & New EY leaders (0-3 years' experience) & More experienced EY leaders (6+ years' experience) \\
\hline \multirow[t]{3}{*}{$\begin{array}{l}\text { How is EY leadership dif- } \\
\text { ferent to whole- school } \\
\text { subject leadership? }\end{array}$} & $\begin{array}{l}\text { 'Smaller to manage compared to whole-school } \\
\text { subject leadership.' (School A: Teacher A) }\end{array}$ & $\begin{array}{l}\text { 'Smaller team, therefore no issues. Context of EY } \\
\text { is different to that in the rest of the school - } \\
\text { curriculum, and assessment opportunities.' } \\
\text { (School A: Teacher B) }\end{array}$ \\
\hline & $\begin{array}{l}\text { 'Easier to manage, but does not link to the rest } \\
\text { of the school.' (School B: Teacher B) }\end{array}$ & $\begin{array}{l}\text { 'Different curriculum. Some staff don't really under- } \\
\text { stand EY in the school. EY is seen to be a "bolt on" to } \\
\text { the rest of the school. It's an island in the middle of } \\
\text { the school as it's a different curriculum, and a dif- } \\
\text { ferent way of doing things.' (School B: Teacher B) }\end{array}$ \\
\hline & $\begin{array}{l}\text { 'More child-centered and creative, also leading } \\
\text { one year group rather than two or three.' } \\
\text { (School C: Teacher A) }\end{array}$ & $\begin{array}{l}\text { 'You are leading a group of individuals who share EY } \\
\text { knowledge and understanding, therefore it's easier to } \\
\text { manage EY.' (School C: Teacher B) }\end{array}$ \\
\hline
\end{tabular}

leadership traits of compassion, humbleness, inspiration and the ability to deal with conflict to be utilised in far more creative ways. Creativity, even for experienced teachers and head teachers, is a skill on its own. For example, the context of the school, its history, the politics and the culture of the organisation impact on the way senior leaders practise and model their leadership style. The need for individual support is becomes even more crucial (Leithwood \& Jantzi, 2005).

One head noted the need for 'giving [them] freedom to do what they need to do, so staff have autonomy, helped to bridge that gap between child-centred leadership to adultcentred leadership'. Teacher F commented on the time taken to 'belong' before respect is accorded to you, which may well be to do with changing practitioners' conceptions of the profession and what still remain the difficulties of constructing an inclusive professionalism. EY practitioners should take up the challenge to question their professional identity and how they interact with the social structures described by Greenfield \& Ribbins (1993).

The results in Table 5 indicate that as EY is contextually so different to the rest of the school, there is very little whole-school understanding of what it actually involves. Both groups of practitioners reflected that EY leadership focuses on the child as the heart of the learning and teaching process. Most head teachers explained that leading a curriculum area is very different to taking on wholeschool initiatives, pointing to the strategies they had in place at their school. These included giving the EY practitioner autonomy: 'I am not an EY professional and therefore I leave the EY bit to the EY team'; 'exchanging roles between EY and the rest of the school'; 'membership of curriculum group where a whole-school drive is important'. One head commented that they 'ensured that everyone in the school worked as a team, sharing ideas and delivering the same vision for the school'.

Creating and sustaining a focused vision becomes an important factor of effective organisations where a central leadership role becomes the driver for change, as advocated by researchers (Leithwood \& Jantzi, 2005; Zhong, 2009; Miller \& Cable, 2011). Whether it is through transformational or distributive leadership, or using male or female traits of leadership (Boone, 2004), more important in our view is an understanding and application of the skills to leadership and management activities and it should be the responsibility of all professionals in the EY sector. Rodd's (2006) typology of an early childhood leader may be a good point to start the staged development process. However, the wider leadership theory suggests that the role of leadership in EY is mainly that of 'leadership for learning' (SirajBlatchford and Manni, 2007), a point not understated in our analysis.

Reflecting on the comments in Table 6, we note that all EY practitioners sometime into their careers have had some opportunity for training and development. What is different is that the new early leaders had an earlier exposure to leadership and management theories than the more experienced EY leaders. The implication is that the earlier group felt more confident in their ability to reflect on leadership roles, whereas the latter group took some time to realise their potential for developing their own leadership style. 
Table 6. How the school supports the leadership role of the two Early Years practitioner groups

\begin{tabular}{|c|c|c|}
\hline Question & New EY leaders (0-3 years' experience) & More experienced EY leaders (6+ years' experience) \\
\hline \multirow[t]{3}{*}{$\begin{array}{l}\text { How has your school } \\
\text { supported you in your } \\
\text { leadership role? }\end{array}$} & $\begin{array}{l}\text { 'Observed subject leaders teaching as part of my } \\
\text { NQT targets. Attended cluster subject meetings to } \\
\text { gain better understanding of the given role.' } \\
\text { (School A: Teacher A) }\end{array}$ & $\begin{array}{l}\text { 'No idea what to do when I started. Spent a lot of } \\
\text { time trying to raise the money to support ICT. I } \\
\text { knew I had to write a policy.' (School A: Teacher B) }\end{array}$ \\
\hline & $\begin{array}{l}\text { 'Shadowed other subject coordinators. Mentor sup- } \\
\text { port for leadership role.' (School B: Teacher A) }\end{array}$ & $\begin{array}{l}\text { 'Observations in other settings Visits to EY } \\
\text { advisors, and lead EY practitioners. Attended } \\
\text { national conferences over the years for EY.' } \\
\text { (School B: Teacher B) }\end{array}$ \\
\hline & $\begin{array}{l}\text { 'External courses matched to my skills. Observed } \\
\text { other EY individuals in other settings. Did home } \\
\text { visits with more experienced staff, so was able to } \\
\text { build relationships with parents very early.' (School } \\
\text { C: Teacher A) }\end{array}$ & $\begin{array}{l}\text { 'There was very little support in the first few years } \\
\text { of teaching, but this has changed over the years as } \\
\text { EY has become more important.' (School C: } \\
\text { Teacher B) }\end{array}$ \\
\hline
\end{tabular}

Table 7. What are the challenges for head teachers to address some of the differences?

\begin{tabular}{|c|c|c|}
\hline Question & New EY leaders (0-3 years' experience) & $\begin{array}{l}\text { More experienced EY leaders (6+ years' } \\
\text { experience) }\end{array}$ \\
\hline \multirow[t]{3}{*}{$\begin{array}{l}\text { How could senior leaders sup- } \\
\text { port you more to help you in } \\
\text { your role of EY leader? }\end{array}$} & $\begin{array}{l}\text { 'Looking at examples of subject coordinator } \\
\text { paperwork. Time to ask different staff what } \\
\text { they do for their subject leadership, to com- } \\
\text { pare against EY.' (School A: Teacher A) }\end{array}$ & $\begin{array}{l}\text { 'Needs to be a clear set of roles and responsibil- } \\
\text { ities. Attitude among some staff that EY lead- } \\
\text { ership is not as important as core subjects. If } \\
\text { leadership responsibilities were rotated, then } \\
\text { all staff would have a better understanding of } \\
\text { expectations and what happens in EY. Some } \\
\text { staff have very little appreciation of how hard it } \\
\text { can be to lead EY.' (School A: Teacher B) }\end{array}$ \\
\hline & $\begin{array}{l}\text { 'By having money to buy resources, but this is } \\
\text { difficult as there are more important priorities } \\
\text { in the school.' (School B: Teacher A) }\end{array}$ & $\begin{array}{l}\text { 'I have the freedom to do what I want in EY as I am } \\
\text { seen to be the EY expert in the school. To have } \\
\text { more opportunities to see EY leaders in other } \\
\text { settings to see how they manage their role.' } \\
\text { (School B: Teacher B) }\end{array}$ \\
\hline & $\begin{array}{l}\text { 'Allowing some money for large resources. By } \\
\text { coming into EY to see what we do, as we feel a } \\
\text { little isolated at times.' (School C: Teacher A) }\end{array}$ & $\begin{array}{l}\text { 'For other senior leaders to have some under- } \\
\text { standing of what happens at this part of the } \\
\text { school. To include us more in school training } \\
\text { sessions e.g. if we have inset on Maths, then } \\
\text { there is very little on EY.' (School C: Teacher B) }\end{array}$ \\
\hline
\end{tabular}

The head teachers commented favourably about the potential of the new EY leaders but then being very open about developing the potential of all staff. Some of the initiatives to develop leaders in their schools included: 'sending them on national courses that they have to feedback on to whole staff'; 'encourage them to observe others to share good practice'; 'we have a curriculum rotation system whereby all staff have to have responsibility for different areas of learning in addition to their specialism areas ... these additional areas of responsibility tend to be rotated every few years'. The evidence supports Rodd's (2006) notion of a staged development process for leadership. What did not emerge from our small-scale study are the implications for the preparation of EY leaders for a community leadership role or how they would handle the multiplicity of roles advocated in Muijs et al.'s (2004) study.

The evidence in Table 7 suggests that practitioners want the 'rest' of the school to recognise their status and that they require head teachers to encourage greater wholeschool working to break down perceived barriers. They also wanted more support from other colleagues through dialogue about pedagogy or assessment, or resources generally, and more specifically to be valued as EY practitioners with valuable skills to offer, to be able to innovate and to be offered new challenges and opportunities. The head teachers were clearly aware of many such reflections and were developing or had well developed structures and systems for collaboration and whole-team working. One head teacher explained how important it was to 'know whether staff want to be developed as leaders' and how they demonstrated clear support through 'helping staff to recognise that they are leaders in their own right'. Another head described the limitations of their small school in terms of staff development, stating that 'the difficulty we have is that because we are a small school, we only have two parttime EY individuals, therefore collaboration within an EY team is limited'.

Whole-school understanding of the role of EY was indeed a challenge as noted in this comment by one head: 'Leadership in EY is so different - that is getting the staff 
to recognise that they are leaders in their area just as much as other leaders in the school'. So the challenge for head teachers is centred on demystifying the notion of EY practice and a better understanding of professionalism. Moss (2006) notes some of the concerns of professional identity, status and positioning of EY work, and we advocate from our evidence the need to challenge the existing paradigm and ways of doing things and encourage EY professionals to create their own identity, which may require difficult questions with uncomfortable answers.

\section{Conclusions}

In conclusion, our study illuminated some understanding and awareness of the critical nature of EY leadership in improving pedagogical reform, but more evidence is required to reconceptualise how EY practitioners develop a more holistic approach. From the limited evidence, we can discern that the culture of the organisation has a large impact on the way leaders view their staff as teacher leaders. Where there is a clear vision (Gronn, 1999), modelled for furthering teacher leadership and management abilities, the transformation of such skills by offering intellectual stimulus and providing individual support to early and later years practitioners (Leithwood \& Jantzi, 2005) is more evident. We also gather from the evidence that these early and experienced EY practitioners develop a better insight into their own practice when they can observe the various leadership styles of both men and women (Boone, 2004) in different cultural contexts (Cheng, 1995; Dimmock \& Walker, 2000, 2005), and see if the gender of leaders is material or not in the EY context. The school organisation and the culture has therefore to be facilitative, allowing these early years practitioners to take risks and develop their own leadership styles when dealing with people and change management (Muijs et al., 2004).

University training for teacher training students has also changed in England to address the changes in EY nationally. Equally, these institutions have a role to play in developing the critical faculty of their trainees to understand how to debate issues of sexual orientation and homophobia, if they are to develop a teaching workforce that represents men and women in all phases of the education system. So there has to be more emphasis on leadership and management, especially in the final year of training and including the final teaching practice in this contentious area. This has led to newer EY practitioners being better prepared for the variety of leadership roles they have to play in their setting in comparison to those EY practitioners who had over six years teaching experience. More experienced practitioners had a more academic style of training at their universities, in which there was more focus on their subject specialism and less on leadership and management, therefore they were less prepared for leadership roles within their schools. There is an urgent need for further studies which might expand on this one and usefully look at the impact on and perceptions and roles of other stakeholders, including critical analysis of the strategic leadership development practised across the whole school setting (Davies \& Davies, 2005) in urban and rural settings and small and large schools.

\section{References}

Adams, K. (2008) 'What's in a name? Seeking professional status through degree studies within the Scottish Early Years context'. European Early Childhood Education Research Journal, 16(2), 196-209.

Armstrong, M. \& Stephens, T. (2006) A Handbook of Management and Leadership: A Guide to Managing for Results. London: Kogan Page.

Aubrey, C., Godfrey, R., Harris, A. \& Dahl, S. (2006) 'How Do They Manage?' An Investigation of Early Childhood Leadership. Symposium at British Educational Research Association Conference, University of Warwick, 9 September.

Bennis, W. G. \& Nanus, B. (1995) Leaders: The Strategies for Taking Charge. New York: Harper \& Row.

Bolman, L. G. \& Deal, T. E. (1997) Reframing Organisations: Artistry, Choice and Leadership, 2nd edn. San Francisco: Jossey-Bass.

Boone, C. (2004) 'A Comparison of Male and Female Principals' Perception of their Leadership Behaviors in High-Achieving North Carolina Schools'. Unpublished doctoral dissertation, Western Carolina University, North Carolina.

Bush, T. (2010) 'Authenticity in research - reliability, validity and triangulation'. In Ann R. J. Briggs \& Marianne Coleman (eds), Research Methods in Educational Leadership and Management. London: Sage.

Cable, C. \& Miller, L. (2011) 'A new professionalism', in L. Miller \& C. Cable (eds), Professionalization, Leadership and Management in the Early Years. London: Sage.

Chakraborty, D. (2003) 'Leadership in the East and West: a few examples', Journal of Human Values, 9, 29-52.

Cheng, K. (1995) 'The neglected dimension: cultural comparison in educational administration'. In $\mathrm{K}$. Wong \& $\mathrm{K}$. Cheng (eds), Educational Leadership Change: An International Perspective. Hong Kong: Hong Kong University Press.

Children's Workforce Development Council (CWDC) (2011a) Early Years Professional Status. Online at: http://www. cwdcouncil.org.uk/eyps (accessed January 2011).

Children's Workforce Development Council (CWDC) (2011b) National Standards for Children's Centre Leaders. Online at: http://www.cwdcouncil.org.uk/ (accessed January 2011).

Cohen, L., Manion, L. \& Morrison, K. (2002) Research Methods in Education. London: RoutledgeFalmer.

Davies, B. \& Davies, B. J. (2005) 'Strategic leadership'. In B. Davies (ed.), The Essentials of School Leadership. London: Sage.

Department for Education and Skills (DfES) (2007a) Early Years Foundation Stage. London: DfES.

Department for Education and Skills (DfES) (2007b) National Standards for Leaders of Children's Centres. Nottingham: DfES.

Dimmock, C. \& Walker, A. (2000) 'Globalisation and societal culture: redefining schooling and school leadership in the twenty-first century'. Compare, 30(3), 303-12. 
Dimmock, C. \& Walker, A. (2005) Educational Leadership: Culture and Diversity. London: Sage.

Drever, E. (1995) Using Semi-structured Interviews in SmallScale Research. Edinburgh: Scottish Council for Research in Education.

Dunlop, A. W. (2002) Scottish Nursery Teachers' Concepts of Leadership. Paper presented at the Third Warwick International Early Years Conference, University of Warwick, 18-20 March.

Ebbeck, M. \& Waniganayake, M. (2003) Early Childhood Professionals: Leading Today and Tomorrow. Sydney: MacLennan \& Petty.

Fogelman, K. \& Comber, C. (2007) 'Surveys and sampling'. In Ann R. J. Briggs \& Marianne Coleman (eds), Research Methods in Educational Leadership and Management. London: Sage.

Greenfield, T. B. \& Ribbins, P. (eds) (1993) Greenfield on Educational Administration: Towards a Human Science. London: Routledge.

Gronn, P. (1999) The New Work of Educational Leaders. London: Cassell.

Hall, V. (1997) 'Dusting off the phoenix - gender and educational leadership revisited'. Educational Management Administration Leadership, 25(3), 309-24.

Hogue, M. \& Lord, R. G. (2007) 'A multilevel, complexity theory approach to understanding gender bias in leadership'. Leadership Quarterly, 18(4), 370-90.

Johnson, P. \& Kossykh, Y. (2008) Early Years, Life Chances and Equality: A Literature Review. Manchester: Equality and Human Rights Commission.

Knight, P. T. (2002) Small-Scale Research. London: Sage.

Leithwood, K. \& Jantzi, D. (2005) 'Transformational leadership'. In B. Davies (ed.), The Essentials of School Leadership. London: Sage.

Lloyd, E. (2008) 'The interface between childcare, family support and child poverty strategies under New Labour: tensions and contradictions'. Social Policy and Society, 7(4), 479-94.

McMillan, D. \& Walsh, G. (2011) 'EY professionalism: issues, challenges and opportunities'. In L. Miller \& C. Cable (eds), Professionalization, Leadership and Management in the Early Years. London: Sage.

MacNaughton, G. (2000) Rethinking Gender in Early Childhood Education. Sydney: Allen \& Unwin.

Marshall, C. \& Rossman, G. (1995) Designing Qualitative Research. Thousand Oaks, CA: Sage.

Miller, L. \& Cable, C (eds) (2011) Professionalization, Leadership and Management in the Early Years. London: Sage.

Moss, P. (2006) 'Structures, understandings and discourses: possibilities for re-envisioning the Early Years childhood worker'. Contemporary Issues in Early Childhood, 7(1): 31-41.

Moyles, J. (2006) Effective Leadership and Management in the EY. Maidenhead: Open University Press.

Muijs, D., Aubrey, C., Harris, A. \& Briggs, M. (2004) 'How do they manage? A review of the research in early childhood'. Journal of Early Childhood Research, 2, 157-69.

Murray, A. (1996) 'We all love Charles: men in child care and the social construction of gender'. Gender and Educational Studies, 45, 276-92.
National College for School Leadership (NCSL) (2010) 'Leadership learning days for the Children's Centre Leaders Network (CCLN)'. Online at: http://www.nationalcollege.org.uk/index/ professional-development/ccln/ccln-dates-and-locations.htm (accessed October 2010).

National College of Leadership and Children's Services (NCLCS) (2011) 'The National Professional Qualification in Integrated Centre Leadership (NPQICL)'. Online at: http://www.nationalcollege.org.uk/index/professional-development/npqicl.htm (accessed Janary 2011).

O'Sullivan, J. (2010) Leading to Make a Difference. London: Early Years Foundation. Online at: http://www.leyf.org.uk (accessed 26 January 2010).

Paton, M. Q. (2002) Qualitative Research and Evaluation Method. Newbury Park, CA: Sage.

Randall, V. (2000) The Politics of Child Day Care in Britain. Oxford: Oxford University Press.

Roberts-Holmes, G. \& Brownhill, S. (2011) 'Where are the men? A critical discussion of male absence in the EY'. In L. Miller \& C. Cable (eds), Professionalization, Leadership and Management in the Early Years. London: Sage.

Rodd, J. (2006) Leadership in Early Childhood. Maidenhead: Open University Press.

Sadek, E. \& Sadek, J. (2004) Good Practice in Nursery Management, 2nd edn. Cheltenham: Nelson Thornes.

Shakeshaft, C. (1989) Women in Educational Administration. Newbury Park, CA: Sage.

Siraj-Blatchford, I. \& Manni, L. (2007) Effective Leadership in the Early Years Sector (ELEYS) Study. London: Institute of Education, University of London.

Solly, K. (2003) What Do Early Years Leaders Do to Maintain and Enhance the Significance of the Early Years. A paper on a conversation with Kathryn Solly held at the Institute of Education, University of London, 22 May.

Spillane, J., Halverson, R. \& Diamond, J. B. (2001) 'Investigating school leadership practice: a distributive perspective'. Educational Researcher, 30(3), 23-8.

Stevens, P., Lupton, R., Mujtaba, T. \& Feinstein, L. (2007) The Development of Impact of Young People's Social Capital in Secondary Schools, Research Report No.24. London: Centre for Research on the Wider Benefits of Learning, Institute of Education, University of London.

Stonewall (2007) Sexual Orientation Research Review, Report to the Equalities Review. London: Cabinet Office.

Sumsion, J. (2010) 'Negotiating otherness: a male early childhood educators gender positioning'. International Journal of Early Years Education, 8(2), 129-40.

Wallace, S. \& Gravells, J. (2010) 'Telling a compelling story: managing inclusion in college and further education'. Management in Education, 24(3), 102-6.

Waniganayake, M., Morda, R. \& Kapsalakis, A. (2000) 'Leadership in child care centres: is it just another job?' Australian Journal of Early Childhood, Special Issue on Management and Leadership, 28(1), 13-19.

Whalley, M. E. (2011) 'Leading and managing in the EY'. In L. Miller \& C. Cable (eds), Professionalization, Leadership and Management in the Early Years. London: Sage.

Yin, R. K. (2003) Case Study Research: Design and Methods, 3rd edn. London: Sage. 
Zhong, W. (2009) 'Leadership Construction: An Exploratory Case Study of Two Exemplary Female Principals in Urban Primary Schools in Mainland China'. Unpublished doctoral dissertation, Queensland University of Technology, Australia.

\section{Biography}

Malini Mistry is a Senior Lecturer in Early Years

Education and Head of Year 2 at the University of
Bedfordshire with research interest in Early Years and pupils who have English as an Additional Language. Email: malini.mistry@beds.ac.uk

Krishan Sood is an MA Programme Leader at Nottingham Trent University with research interest in Leadership for Diversity and English as an Additional Language. E-mail: krishan.sood@ntu.ac.uk 